NOTE

\title{
THE IMPACT OF ERTA AND TEFRA ON TAX CREDITS FOR HISTORIC PRESERVATION
}

\section{INTRODUCTION}

In its report accompanying the Economic Recovery Tax Act of 1981 (ERTA), ${ }^{1}$ the Senate Finance Committee explained why it was proposing a new, more generous scheme of investment tax credits for rehabilitating qualified buildings.

The tax incentives for capital formation provided in other sections of this bill [i.e., the new depreciation provisions] might have the unintended and undesirable effect of reducing the relative attractiveness of the existing incentives to rehabilitate and modernize older business structures. Investments in new structures and new locations, however, do not necessarily promote economic recovery if they are at the expense of older structures, neighborhoods and regions. . . .

The increased credit for rehabilitation expenditures is intended to help revitalize the economic prospects of older locations and prevent the decay and deterioration characteristic of distressed economic areas. ${ }^{2}$

While the tax system encouraged rehabilitation in the Tax Reform Act of $1976^{3}$ and the Revenue Act of $1978,{ }^{4}$ ERTA greatly expanded the size and the scope of the available tax credits so that they offer considerable economic advantages to investors. Despite some lessening of this generosity in the Tax Equity and Fiscal Responsibility Act of 1982 (TEFRA), ${ }^{5}$ the rehabilitation credits are still the most generous credits in the tax code and have spurred enormous growth in rehabilitation of older buildings. ${ }^{6}$

This note will focus on why Congress decided to legislate in this area, and on whether the goals of revitalization and prevention of decay are best achieved through tax incentives, unassisted market mechanisms, or direct government spending. Before undertaking this analysis, however, it is useful to examine the history of tax incentives in the area of historic preservation.

1. Pub. L. No. 97-84, 95 Stat. 172.

2. S. Rep. No. 144, 97th Cong., lst Sess. 72, reprinted in 1981 U.S. Code Cong. \& Ad. News 177 (emphasis added).

3. Pub. L. No. 94-455, 90 Stat. 1520; see infra notes 7-19 and accompanying text.

4. Pub. L. No. 95-600, 92 Stat. 2763; see infra notes 20-30 and accompanying text.

5. Pub. L. No. 97-248, 96 Stat. 324; see infra notes 51-55 and accompanying text.

6. U.S. General Accounting Office, Information on Historic Preservation Tax INCENTTVES 8-9 (1984); see infra note 65. 
II

\section{INCENTIVES BEFORE ERTA}

\section{A. Tax Reform Act of $\mathbf{1 9 7 6}$}

The first tax-based provisions pertaining to rehabilitation of structures were contained in the Tax Reform Act of $1976,{ }^{7}$ which sought to put rehabilitation and new housing on an equal footing. ${ }^{8}$ Senator J. Glenn Beall, the sponsor of the provisions, felt that the pre-existing tax system worked in a "very direct and definite way against enlisting private funds in historic restoration projects," and saw his legislation as a method of "updat[ing] our tax system so as to help redirect and achieve socially desirable goals."

The Act added new Internal Revenue Code sections 191 and 167(o).10 Section 191 allowed amortization over a sixty-month period of the rehabilitation expenses of certified historic structures (CHS's) (those on the National Register or located in a registered historic district and certified by the Secretary of Interior). ${ }^{11}$ To be certified as a historic structure, a building must meet one of the following criteria: (1) be associated with historically significant events; (2) be associated with the lives of significant persons; (3) embody the distinctive characteristics of a type, period, or method of construction; (4) represent the work of a master or possess high artistic value; or (5) yield or be likely to yield important historical information. ${ }^{12}$ Age is not a specific factor, although it may influence the application of the above criteria. ${ }^{13}$ Alternatively, section 167 permitted an owner of a certified historic structure which was "substantially rehabilitated" to depreciate his qualified rehabilitation expenditures and his prerehabilitation adjusted basis at the same rate as new buildings ${ }^{14}(200 \%$ declining balance for residential structures and $150 \%$ declining balance for commercial structures over a fortyyear life), ${ }^{15}$ instead of using sixty-month amortization which was limited to only rehabilitation expenses by section $191 .{ }^{16}$ "Substantially rehabilitated" structures were defined as those in which rehabilitation expenses exceeded the greater of the adjusted basis of the property or $\$ 5,000 .{ }^{17}$

7. Pub. L. No. $94-455, \$ 2124,90$ Stat. $1520,1916,1918$.

8. A Handbook on Historic Preservation Law 460 (C. Duerksen ed. 1983) [hereinafter cited as HANDBOOK].

9. 121 Cong. Rec. 3004 (1975).

10. Pub. L. No. 94-455, \& 2124 (a), (d), 90 Stat. 1520, 1916, 1918.

11. I.R.C. \& 191(a), (d) (West 1978), repealed by Economic Recovery Tax Act of 1981, Pub. L. No. 97-34, 8 212(d)(1), 95 Stat. 172, 239.

12. 36 C.F.R. $\$ 60.6(1981)$.

13. See infra note 68 .

14. I.R.C. \& 167(o) (West 1978), repealed by Economic Recovery Tax Act of 1981, Pub. L. No. 97. 34, \& 212(d)(7), 95 Stat. $172,239$.

15. I.R.C. $\& 167$ (a), (b), (j) (West 1980).

16. I.R.C. 191(a), (d), repealed by Economic Recovery Tax Act of 1981, Pub. L. No. 97-34, $8212(d)(1), 95$ Stat. $172,239$.

In reality, the 60 -month amortization will yield much higher tax savings than the $200 \%$ declining balance method and would have been favored in most instances.

17. I.R.C. \& 167(o)(2) (West 1978), repealed by Economic Recovery Tax Act of 1981, Pub. L. No. 97-34, \& 212(d)(1), 95 Stat. 172, 239. 
The impact of the law can best be illustrated by an example. If, in 1976, a person purchased a seventy-five-year-old tobacco warehouse with an adjusted basis of $\$ 100,000$ for the purpose of converting it into condominiums, he would be eligible for tax relief only if the building were certified as a historic structure. Assuming that the building were designated a CHS, the size of the tax break would be determined by the size of the rehabilitation expenditure. For this warehouse to meet the "substantially rehabilitated" standard and thus qualify for section 167 accelerated depreciation of both qualified rehabilitation expenditures and prerehabilitation adjusted basis, the owner would have to invest at least $\$ 100,000$ (the adjusted basis). Otherwise, under section 191, he would be allowed only to amortize his rehabilitation expenses (as opposed to the adjusted basis and the rehabilitation expenses). Since the five-year write-off for the rehabilitation expenses under section 191 was really only slightly less attractive than the accelerated depreciation under section 167 , however, the investor would not be likely to opt for "substantial rehabilitation" solely for the additional tax breaks it brought. ${ }^{18}$

While the 1976 Act added some incentives for the rehabilitation of historic buildings, it did not generate much new preservation activity because it was limited to CHS's, which had to be nominated and approved by local, state, and federal historic preservation agencies. ${ }^{19}$ The 1976 Act did, however, generate attention to the problem of a decaying urban infrastructure, thereby paving the way for future legislation.

\section{B. Revenue Act of 1978}

Two years later, incentives for renovation and restoration were further expanded with the passage of the Revenue Act of 1978.20 This Act initiated the use of tax credits for rehabilitation and broadened the scope of the incentives by allowing tax credits for non-CHS's. Code section $48(\mathrm{~g})$, added by the Act, ${ }^{21}$ gave a $10 \%$ investment tax credit ${ }^{22}$ to commercial buildings at least twenty years old which: (1) were rehabilitated; (2) had originally been placed in service before the beginning of rehabilitation; and (3) retained 75\% of prior existing external walls as external walls. ${ }^{23}$ Any costs arising from the acquisition of the property to be rehabilitated or from the construction of new additions were not included in the credit. ${ }^{24}$ In addition, all rehabilitation expenses for CHS's needed to be certified as being consistent with the "historic character of such property or the district in which such property is

18. See supra note 16 .

19. 36 C.F.R. \& $60.2(1981)$.

20. Pub. L. No. 94-455, \& 315, 92 Stat. $2763,2828$.

21. I.R.C. \& 48(g) (West 1980), amended by Economic Recovery Tax Act of 1981, \& 212(b), 95 Stat. 172, 236-37.

22. I.R.C. \& 46(a)(2)(B) (Lawyers Co-op. 1984).

23. I.R.C. $88(\mathrm{a})(\mathrm{l})(\mathrm{E})$, (g) (West 1980), amended by Economic Recovery Tax Act of 1981, 8212 (b), 95 Stat. 172, 236-87.

24. I.R.C. \& 48(g)(2)(B) (West 1980), amended by Economic Recovery Tax Act of 1981, \& 212(b), 95 Stat. 172, 236-37. 
located" before a tax credit could be obtained. ${ }^{25}$ Rehabilitation expenses for non-CHS's did not have to be so certified. ${ }^{26}$

The warehouse condominium owner in the example above would be in a slightly better position as a result of the 1978 Revenue Act. If his project were certified as a historic structure, he would receive a $10 \%$ investment tax credit (i.e., $10 \%$ of his rehabilitation expenditures would be credited against his tax) and would be allowed section 191 amortization in addition to the tax credit.27 Further, if he had "substantially rehabilitated" he could have elected the accelerated depreciation provisions on the rehabilitation expenditures with the tax credit. 28

Although the effect of this Act was to extend preservation tax breaks to a much wider class of structures, the amount of rehabilitation activity remained fairly low. ${ }^{29}$ Nevertheless, like the 1976 Act, the 1978 Revenue Act had significance beyond its actual use in that it stimulated interest in the idea of using tax credits for preservation. Proponents of preservation saw these credits as a strong beginning ${ }^{30}$ and pressed Congress for further reform. Congress responded with greatly increased incentives in ERTA.

\section{III}

\section{INCENTIVES IN ERTA}

\section{A. New Tax Credits}

As the preservationists had urged, investment tax credits for qualified rehabilitation of older buildings were greatly expanded under ERTA. Instead of an across-the-board $10 \%$ tax credit and special depreciation provisions, ERTA set up a three-tiered credit: a $15 \%$ tax credit for qualified rehabilitation expenses on thirty- to forty-year old industrial/commercial buildings; a $20 \%$ credit for qualified rehabilitation expenses on industrial/commercial buildings over forty years old; and a $25 \%$ credit for qualified rehabilitation expenses on certified historic structures. ${ }^{31}$ Unlike the $15 \%$ and $20 \%$ credits, the $25 \%$ credit could be used for residential as well as commercial/industrial CHS's. ${ }^{32}$

These new credits were to be taken in lieu of the regular credits and the energy percentage credits otherwise applicable to the rehabilitated

25. I.R.C. $\$ 48(\mathrm{~g})(2)$ (B) (West 1980), amended by Economic Recovery Tax Act of 1981, $\$ 212$ (b), 95 Stat. 172, 236-37; I.R.C. $\$ 191$ (d)(4) (West 1980), repealed by Economic Recovery Tax Act of 1981 , $\$ 212(d)(1), 95$ Stat. $172,239$.

26. See I.R.C. $\$ 48(\mathrm{~g})(2)(B)$ (West 1980), amended by Economic Recovery Tax Act of 1981, \& 212(b), 95 Stat. 172, 236-37.

27. See supra note 16.

28. See supra note 17.

29. See infra note 60 .

30. See HandBook, supra note 8 , at 464 .

31. Pub. L. No. 97-34, 8212,95 Stat. 172, 236 (codified at I.R.C. $\$$ 46(a)(2)(F) (Lawyers Co-op. 1984)).

32. I.R.C. $\& 48(\mathrm{~g})(3)$ (Lawyers Co-op. 1984); id. \& 48(a)(3)(D). 
property. ${ }^{33}$ In addition, in each tax year, any taxpayer was limited to a maximum of $\$ 25,000$ in credits for the first $\$ 25,000$ of tax liability and $90 \%$ of tax liability in credits for tax liability above $\$ 25,000 .{ }^{\$ 4}$

\section{B. Rules for Qualified Rehabilitation}

The rules for what constitutes "qualified rehabilitation" were also changed. Instead of merely having to be "rehabilitated," buildings now had to be "substantially rehabilitated." 35 The requirements for "substantial rehabilitation" are similar to those found in former Code section $167(0) ;^{\mathbf{3 6}}$ that is, "qualified rehabilitation expenditures during the twenty-four month period ending on the last day of the taxable year [must] exceed the greater of (I) the adjusted basis of such property or (II) $\$ 5000$." 37 For the tobacco warehouse owner in the earlier example, this provision would mean that he would have to invest a minimum of $\$ 100,000$ in the project (the adjusted basis of the property) to qualify for the higher tax credits found in ERTA.

In addition, what constituted "qualified rehabilitation expenditures" was limited in comparison to earlier law. While general capital expenditures for property and rehabilitation were still included, ${ }^{38}$ the new provisions did not permit any method of accelerated depreciation to be combined with a tax credit. ${ }^{39}$ In other words, if the warehouse owner elected to take a tax credit for his rehabilitation expenses, he could only use straight-line depreciation on the value of the improvements. Nevertheless, because ERTA shortened recovery periods for depreciation in its Accelerated Cost Recovery System (ACRS), even straight-line depreciation would allow our owner to recover his cost at the end of fifteen years, ${ }^{40}$ rather than the thirty to thirty-five years as under the previous law. ${ }^{41}$ ERTA also allowed owners of rehabilitated CHS's to depreciate the full amount of the increase in basis resulting from the

33. Id. $\S 46(\mathrm{a})(2)(\mathrm{F})(\mathrm{ii})$. The regular investment tax credit is $10 \%$ and the energy tax credit is either $10 \%$ or $15 \%$. Id. $\$ 46$ (a)(2)(B)(C). These credits can be used in combination with each other subject to the limitations in I.R.C. \$ 46(a)(3). See infra note 34 and accompanying text.

34. I.R.C. \& 46(a)(3) (Lawyers Co-op. 1982), amended by Tax Equity and Fiscal Responsibility Act of 1982 , Pub. L. No. $97-248, \S 205$ (b), 96 Stat. 324, 430 (credit limited to $85 \%$ of tax liability above $\$ 25,000$ ).

35. I.R.C. \& 48(g)(1)(A) (Lawyers Co-op. 1984).

36. See supra notes 14-17 and accompanying text.

37. I.R.C. $\& 48(\mathrm{~g})(1)(\mathrm{C})$ (i) (Lawyers Co-op. 1984). This requirement is made somewhat less onerous by the allowance of a 60-month-rather than the usual 24-month-completion period for rehabilitation projects which reasonably can be expected to be completed in phases. Id. $\$ 48(\mathrm{~g})(\mathrm{l})(\mathrm{C})(\mathrm{ii})$.

38. Id. $\$ 48(\mathrm{~g})(2)$ (A) (note that the class of property has changed slightly because of the new ACRS).

39. Id. $\$ 48(\mathrm{~g})(2)(\mathrm{B})$. In addition to disallowing accelerated depreciation, this provision also explicitly excluded the cost of acquisition and enlargements and restricted expenditures on CHS's to those certified by the Department of Interior as "consistent with the historic character of such property or the district in which such property is located." Id. \& $48(\mathrm{~g})(2)(\mathrm{C})$.

40. I.R.C. \& 168 (c)(2)(D) (West 1982). The owner, if he desired, could opt for a 35- or 45-year recovery period under provisions of ACRS, id. $\$ 168(\mathrm{~b})(3)(\mathrm{A})$. This was changed to 18 years by the Deficit Reduction Act of 1984, Pub. L. No. 98-369, \&111(a)(1), 98 Stat. 494,631.

41. I.R.C. \& 167 (b)(1) (Lawyers Co-op. 1984). 
rehabilitation.42 Thus, our hypothetical investor might have lost somewhat from his inability to use accelerated depreciation, but his gain from the shorter recovery period and full inclusion of his increase in basis should have greatly outweighed any loss from utilizing straight-line depreciation.

\section{ACRS}

ERTA made wholesale changes in depreciation methods through the creation of ACRS. Although it would seem that the prohibition against using accelerated depreciation in conjunction with the tax credit $^{43}$ would make accelerated depreciation irrelevant to the computation of tax for preservation projects, ACRS may apply to the tax on the building's shell. ${ }^{44}$ Because no regulations determining the status of the building's shell have been issued, investors may be able to use the $175 \%$ declining balance method with respect to the value of the building's shell, although the rehabilitation expenditures themselves must be depreciated using the straight-line method. ${ }^{45}$ Using the accelerated method for the shell, however, exposes the owner to recapture penalties if he sells the property before the end of the recovery period. ${ }^{46}$ Therefore, the length of time the investment is expected to be held may determine whether the accelerated method is beneficial to a particular owner.

The crucial impact that ACRS has had on preservation, besides shortening the useful life recovery period, is in offering an alternative to the investment tax credit. The investment choice becomes whether to rehabilitate older structures with tax credits using basically straight-line depreciation or to build new structures using accelerated depreciation and no credit. As will be shown below, from a tax benefit standpoint, it is clearly better to utilize the credit and preserve. ${ }^{47}$

\section{Recapture}

The final major technical consideration for taxpayers contemplating rehabilitation is ERTA's tax credit recapture provision. ${ }^{48}$ "If an owner holds a rehabilitated building for five full years after the building is placed in service, he will not be subject to recapture of any of the investment credit upon the sale of the building." 49 If the building is not held for five years,

42. Pub. L. No. 97-34, \& 212(a), 95 Stat. 172, 238 (1981), repealed by Tax Equity and Fiscal Responsibility Act of 1982, Pub. L. 97-248, \& 205(a)(5)(A), 96 Stat. 324, 429.

By contrast, a non-CHS rehabilitator, when awarded a credit, must subtract the full amount of the credit from the increase in basis caused by rehabilitation. Id. For example, if the depreciable basis were $\$ 150,000$, and the rehabilitation credit $\$ 25,000$, only $\$ 125,000$ would be eligible to be depreciated.

43. I.R.C. \& 48(g)(2)(B)(i) (Lawyers Co-op. 1984).

44. Id. \& $168(\mathrm{f})(1)(\mathrm{C})$.

45. Id. $\$ 168(\mathrm{~b})(2)$ (West 1982).

46. Id. \& 1250(b)(4) (Lawyers Co-op. Supp. 1985).

47. See infra note 56 and accompanying text.

48. Pub. L. 97-34, 811 (g), 95 Stat. 172, 233-34 (codified at 1.R.C. 8 47(a)(5) (Lawyers Co-op. 1984)).

49. Whitebread, Tax Incentives for the Preservation of Historic Properties, 60 TAxes 446, 452 (1982); see I.R.C. 847 (a)(5)(b) (Lawyers Co-op. 1984). 
however, the credit is reduced by $20 \%$ for each year less than five it is held. ${ }^{50}$ For example, if the owner of our historic warehouse was given a $\$ 30,000$ tax credit, but sold the building after two years, his credit would be reduced by $\$ 18,000(60 \%$ of $\$ 30,000)$.

\section{IV}

\section{REDUCTION OF INCENTIVES IN TEFRA}

TEFRA took back some of ERTA's generosity. In particular, it changed the basis reduction rule for CHS's and limited the amount of tax credits that could be taken. ${ }^{51}$ Whereas ERTA exempted the entire $25 \%$ CHS credit from any basis adjustment, ${ }^{52}$ TEFRA reduces the increase in basis of a CHS by $50 \%$ of the credit. ${ }^{53}$ Thus, although a CHS is still given favorable treatment for depreciation, the $12.5 \%$ basis reduction $(50 \%$ of the $25 \%$ credit) gives the $25 \%$ CHS credit less of an advantage over the $15 \%$ and $20 \%$ credits $^{54}$ than it had under ERTA. TEFRA also further limited the amount of overall tax credits that can be taken in a single tax year. Beginning in 1983, the limitation was reduced from $\$ 25,000$ and $90 \%$ of excess tax over $\$ 25,000$ per taxpayer per tax year to $\$ 25,000$ and $85 \%$ of excess tax over $\$ 25,000.55$

The effects of the current credits are demonstrated in the Appendix, where a comparison is made of two potential investments: a rehabilitated older residential building and a new residential building. ${ }^{56}$ Each investment would be in a $\$ 100,000$ condominium unit to be held for five years. The "old unit" would be contained in the now familiar CHS tobacco warehouse and the "new unit" in a luxury residential complex. For purposes of illustration, carrying costs (i.e. rent, management fees, taxes, and interest) and initial investment are the same, although the new unit would have higher depreciation and the old unit would be eligible for the tax credit.

The yield from these investments is quite different, with the historic property producing five-year discounted tax savings of $\$ 39,832.51$ and a positive discounted cash flow of $\$ 3707.42$ and the new condominium having discounted tax savings of $\$ 30,454.91$ and a negative discounted cash flow of

50. See I.R.C. \& 47(a)(5)(b) (Lawyers Co-op. 1984).

51. Pub. L. No. 97-348, \& 205, 96 Stat. 324, 427-29. TEFRA also amended the alternative minimum tax, I.R.C. $\$ 55$ (Lawyers Co-op. 1984), to establish a $20 \%$ floor for all taxpayers. This could cause higher bracket taxpayers to be penalized for their use of rehabilitation and other tax credits because rehabilitation tax credits can offset income in figuring the regular income tax, but not the alternative minimum tax. "Therefore, even though a taxpayer may not have any tax preference items giving rise to an alternative minimum tax liability, he may still incur a substantial alternative minimum tax if the rehabilitation credit offsets a substantial amount of his regular income tax." Whitebread, Historic Preservation Tax Incentives-The Impact of Recent Legislation, 61 TAxes 243, 246 (1983).

52. See supra note 42 and accompanying text.

53. Pub. L. No. 97-248, \& 205(a), 96 Stat. 324, 427 (codified at I.R.C. \& 48(q)(1) (Lawyers Coop. 1984)).

54. See supra note 31 and accompanying text.

55. Pub. L. No. 97-248, § 205(b), 96 Stat. \$24, 420 (codified at I.R.C. $\$ 46$ (a)(3) (Lawyers Coop. 1984)).

56. See Appendix, infra. 
$\$ 5671.50$ (see the Appendix for explanation of figures). Thus it appears that the historic property has a sizeable economic advantage for the investor over the new property ( $31 \%$ larger tax breaks and a positive cash flow).

V

\section{EFFECT OF ERTA AND TEFRA}

\section{A. Size of Tax Credits}

Clearly, the most attractive of the ERTA rehabilitation provisions structures is the increase in the size of the credits. Many observers of preservation activity predict that this increase will effectively eliminate the tax bias in favor of new construction. 57 Some have even concluded that "[n]ot only does rehabilitation . . . enjoy far greater tax benefits in absolute terms than it did previously, but rehabilitation now enjoys significantly greater tax benefits than new construction." 58 This is clearly shown by the example in the Appendix, where "but for" the credit of $\$ 15,000$ the new property would have a substantial tax advantage over the rehabilitated property ( $\$ 6500$ in total tax savings). 59

Even though ACRS has made investment in depreciable assets more attractive by shortening their recovery periods, the rehabilitation credits remain the primary reason some real estate investment decisions will be made in favor of rehabilitation.

Compared to the tax savings of 175 percent declining balance depreciation available to owners of new [sic] constructed residential buildings, the twenty-five percent rehab credit coupled with fifteen-year straight-line recovery grants additional tax savings ranging from seventeen to twenty-three percent of the amount spent on rehabilitation.

The tax system thus provides a sizeable incentive to rehabilitate historic residential buildings. ${ }^{60}$

Like accelerated depreciation deductions, rehabilitation credits are recaptured when the investment is not held for at least five years. ${ }^{61}$ This provision, like the "substantial rehabilitation" provision, is designed to penalize or exclude those investors who are not reasonably dedicated to their rehabilitation project. ${ }^{62}$ By creating an incentive to hold on to properties for at least five years, Congress intended to make rehabilitation a stable investment, rather than a short-term tax shelter. ${ }^{63}$ Although it is too soon to

57. See, e.g., Anthony, Summary of Preservation Tax Incentives in the Economic Recovery Tax Act of 1981, Pres. L. ReP. 2001, 2001 (Prepublication Issue 1981).

58. Gensheimer, Rehabilitation Tax Credits: A Real Estate Tax Shelter of the 1980's, 9 J. REAL EsT. TAX'N 299 (1982).

59. See Appendix, infra.

60. Gensheimer, supra note 58, at 909 (emphasis added). Note that these figures are based on the ERTA rule of no basis adjustment for CHS's. Under TEFRA they are somewhat less.

61. I.R.C. \& 47(a)(5) (Lawyers Co-op. 1984). Unlike accelerated depreciation, however, tax credits may not be taken by subsequent purchasers of historic buildings.

62. S. ReP. No. 144, 97th Cong., 1st Sess. 72, reprinted in 1981 U.S. Code Conc. \& Ad. News 177 ; see supra text accompanying note 2.

63. S. Rep. No. 144, 97th Cong., 1st Sess. 72, reprinted in 1981 U.S. Code Conc. \& Ad. News 177; see supra text accompanying note 2. 
tell whether this provision will discourage poor projects, the penalties seem stiff enough to make investors hold their projects for the full five years.

This five-year lock-in provision does, however, have some adverse policy effects. While this provision would seem to encourage better conceived projects, the fact that many projects are developed before they are sold puts the responsibility of holding the project on the passive investor who bought the unit rather than on the person who developed it. ${ }^{64}$ Thus, the effect of the recapture provision is not to insure a higher standard of quality but to restrict the investor's ability to sell his investment. Furthermore, because any remaining credit is lost when it is recaptured, subsequent purchasers, who will get no tax credit, may not be willing to pay as much for the property. Though the rationale for recapture is to make investors more serious about their rehabilitation projects, it is unclear whether this advantage outweighs the problems of liquidity or marketability.

While it is true that the credits have greatly increased historic restoration activity in general, ${ }^{65}$ there have been other more focused effects. Because pre-ERTA credits were equal across age categories, the type and age of the structure made little difference in rehabilitation decisions. ${ }^{66}$ ERTA made distinctions between structures according to their age and type, granting the largest incentives to rehabilitation of CHS's. ${ }^{67}$ Therefore, other considerations aside, rational real estate investors now looking for the greatest rehabilitation tax benefits will search for a CHS. Naturally, CHS's will be preserved at the expense of other old structures. One may forcefully argue that rehabilitation of CHS's is not economically efficient since economic feasibility (or local sentiment for that matter) is not taken into account when a building is considered for a listing on the National Register of Historic Places. ${ }^{68}$

Yet to argue that the credits have precluded consideration of economic feasibility is to ignore the dynamics of the investment process. If the owner of the tobacco warehouse is a rational investor, he will have examined possible alternative investments (and their rates of return) before purchasing the warehouse. Only if the rate of return, including the tax advantages, from the warehouse is the same or higher than other investments (e.g., older nonhistoric buildings or new buildings), will he invest in the warehouse. To generalize, not all preservation projects, even with effectively increased rates

64. Thus, the developer puts together a package and sells it to an investor who applies for the tax credit.

65. In fiscal year $1977-78$ the total amount of rehabilitation investment amounted to $\$ 140$ million (for 549 projects) while fiscal year 1984 investment is estimated to be $\$ 2.2$ billion (for 4,000 projects). U.S. General Accounting Office, information on Historic Preservation Tax INCENTIVES 9 (1984).

66. See supra notes 21-23 and accompanying text.

67. The new three-tiered credit structure was a $50 \%$ increase in credit for 30 - to 40-year-old buildings, a $100 \%$ increase in credit for buildings over 40 years old, and a $150 \%$ increase in credit for CHS's (i.e., from $10 \%$ to $15 \%$ is a $50 \%$ increase). See supra notes $31-32$ and accompanying text. 325.

68. Hild, Certified Historical Rehabilitation: The Economic Recovery Tax Act of 1981, 1983 CHI. B. REV. 
of return caused by the tax credits, will be as desirable as other investments. There may be historic buildings that would be economically infeasible to rehabilitate even with a $100 \%$ tax credit just as there may be historic buildings whose rehabilitation would be feasible without any tax advantages. While the previous tax incentives caused some interest in historic preservation, the large increase in the number of rehabilitation projects since ERTA ${ }^{69}$ suggests that the ERTA credits put many more potential projects on a par with other noncredited investments. While economic feasibility may not be an explicit criterion in historic certification, it is almost certain that a rational investor will consider the economic impact of a project before undertaking it.

In fact, according to a survey of historic rehabilitation investors conducted by the United States General Accounting Office, more than half of the investors would have invested much less or not at all in historic rehabilitation without tax credits. ${ }^{70}$ This survey was done after the 1978 Revenue Act and before ERTA, but one can only conclude that the results would have been even more striking had the survey been done after the passage of ERTA.

Another issue pertaining to the size of the credits and their impact is the concern that "more and more buildings of marginal historical significance [will be] proposed for listing on the National Register."71 The Senate Budget Committee has estimated that nearly one million buildings are potentially eligible for special tax treatment; ${ }^{72}$ there is no doubt that a portion of them are less historically significant. Because of the competition among potentially certifiable buildings for tax credit qualification, however, this fear of marginal significance seems overstated in that it is much less risky to try to certify an assuredly historic structure than a marginal one. Thus, at least in the near term, the worry about too many marginally significant buildings is precluded by the large number of good historic buildings available.

In addition, the Department of Interior has experienced some delays in processing initial applications and in certifying completed rehabilitation ${ }^{73}$ that could further dissuade the owner of a marginally significant building. Yet the GAO survey found that, despite the delays, most investors were either very or somewhat satisfied with the procedure. ${ }^{74}$ These results lend credence to the view that, although some investors could opt not to take the $25 \%$ CHS credit and could use the $15 \%$ or $10 \%$ credit without having to go through the certification process, most investors were willing to put up with the delays in

69. The total number of projects jumped from 1,654 in 1981 (before ERTA) to 3,639 in 1983. Rehabilitation dollars spent grew from $\$ 738.3$ million (1981) to $\$ 2165$ million (1983). U.S. GENERAL Accounting Office, supra note 65, at 9.

70. Investors who had taken advantage of the $10 \%$ pre-ERTA credit were asked to what extent they would have rehabilitated historic structures without tax incentives. Thirty-six percent said to little or to no extent, $20 \%$ said to some extent, $19 \%$ said to a moderate extent, $12 \%$ said to a substantial extent, and another $12 \%$ said to a very great extent. U.S. General Accounting Office, supra note 65, at 10 .

71. Hild, supra note 30 , at 331 .

72. U.S. General Accounting OfFice, supra note 65, at 10.

73. Id. at 23.

74. Id. at 24. 
return for a larger tax credit. Thus, the certification process has proved not to be a deterrent to investors.

Two other issues also pertain to the availability of credits. First, whereas twenty- to thirty-year-old buildings were included in the $1978 \mathrm{Act}$, the new credit scheme does not include buildings less than thirty years old, except CHS's, which have no age requirement. ${ }^{75}$ This exclusion resulted from congressional sentiment that higher credits were more desirable than credits for all classes of buildings and should not drastically affect preservation activity. ${ }^{76}$

Second, and more important, tax credits for the rehabilitation of residential structures are now available, but only as part of the $25 \%$ CHS credit. ${ }^{77}$ An argument has been made that while it may be proper to allow credits for the rehabilitation of CHS's in some residential areas (e.g., the "gentrification" of historic inner-city areas in Baltimore and Philadelphia), CHS's should not have a tax advantage over older residential buildings that do not have "sufficient architectural or historical significance to warrant a place on the register,"78 and thus do not qualify for tax credits for rehabilitation. Yet because both buildings and districts can be certified as historic, noncertified older residential buildings are eligible for tax credits if they are in a certified historic area. The number of these districts has grown from about 1,200 in 1976 to 3,000 in 1983,79 indicating that this earlier criticism is being answered by the certification of historic districts.

\section{B. Rule Changes Regarding Qualified Rehabilitation Activities}

ERTA's single biggest change in the rules for qualifying as a rehabilitated structure is the requirement of "substantial rehabilitation."80 Under the 1976 Act there was no requirement for "substantial rehabilitation," and some preservationists have estimated that "one-third of the projects certified under the 1976 incentives would fail to qualify under the new investment tax credit law."81 Though it is possible that the "substantial rehabilitation" requirement could limit the number of rehabilitation projects undertaken for the credit, this criticism seems overstated, as is demonstrated by the dramatic increase in the number of projects. If the "substantial rehabilitation" requirement were deterring people from becoming involved in historic preservation, the number of projects might have shrunk or grown more slowly instead of increasing rapidly.

However, the "substantial rehabilitation" standard may have the unintended side effect of distorting the market in rehabilitating housing. In

75. I.R.C. \& 46(a)(2)(F) (Lawyers Co-op. 1984).

76. S. REp. No. 144, 97th Cong., 1st Sess. 72, reprinted in 1981 U.S. Code Cong. \& Ad. News 177; see supra text accompanying note 2.

77. I.R.C. \& 48(a)(3)(D) (Lawyers Co-op. 1984).

78. Hild, supra note 68 , at 332 .

79. U.S. General Accounting Office, supra note 65, at 9.

80. I.R.C. $848(\mathrm{~g})(1)(A)$ (Lawyers Co-op. 1984).

81. HaNDBOoK, supra note 8 , at 468. 
other words, the standard might cause investors first to rehabilitate units in need of substantial repair instead of units in better condition that, without the credits, would have been restored first. In effect, Congress has created an inverse relationship between a project's unassisted (i.e., without the credit) economic feasibility and its ability to secure a credit. If Congress wanted to subsidize certain low return units, such as those in low income neighborhoods, it could have used a less costly mechanism (e.g., direct grants) for doing so. The "substantial rehabilitation" requirement thus creates an incentive for investors to spend more money on units in poor condition rather than smaller amounts on a potentially greater number of units in relatively better condition.

\section{Basis Reduction}

Perhaps due more to the political fallout over ERTA's effect on increasing the deficit than to any particular problems with rehabilitation credits, TEFRA curtailed some of ERTA's largess by reducing the depreciable basis of a CHS by $50 \%$ of the CHS credit. ${ }^{82}$ This change "may take some of the allure out of historic preservation projects, but their tax treatment is still better than any other type of real estate investment, with the possible exception of lowincome housing rehabilitation." 83 In short, since the CHS credit is still larger and its basis reduction is still smaller than the other credits available for rehabilitation, it still should be worth the extra time and effort to have an eligible project certified. ${ }^{84}$ The basis change simply puts the CHS credit more in line with similar credits like the investment tax credit, which also requires a basis reduction of $50 \%$ of the credit.

\section{Summary of the Effects}

The first part of this note has shown that changes made in ERTA significantly increased the favorability of investments in older buildings and even more so in certified historic structures. While TEFRA reduced this advantage somewhat, the inducements in the tax code for historic rehabilitation are still quite generous. In the remaining portion of this note these inducements will be considered as part of larger framework of investment decisions.

82. I.R.C. \& 46(a)(2) (Lawyers Co-op. 1984).

83. HandBook, supra note 8 , at 468 .

84. Id. at 479. 


\section{Investment Effects of Rehabilitation Tax Credits}

\section{A. Rehabilitation versus New Construction}

Most observers feel that, from a tax standpoint, the tax incentives in ERTA make rehabilitation more desirable than new construction. ${ }^{85}$ It can be argued, however, that although preservation is a useful objective, the tax code may now encourage too much of it at the expense of other equally useful real estate investments. With ERTA tipping the scales in favor of rehabilitation, marginal older buildings, previously economically infeasible to rehabilitate, may be seized upon as investment opportunities. On its face this action is not detrimental, except when the rehabilitation is at the expense of an equally worthy new project. While not every rehabilitation project will effectively displace other investments, ${ }^{86}$ rehabilitation projects will now assume the status of "most favored real estate investment."

If the goal of the ERTA credits were simply to remove the disincentives from rehabilitation, why is there now a similar tax disincentive for new construction? Should there not be a truly neutral tax choice between new construction and rehabilitation?

An argument can be made that in order to have a neutral choice between rehabilitation and new construction there must be equivalent tax treatment. Such a contention does not focus on the purpose behind these credits. The credits in ERTA were not designed to make the tax system neutral. Congress saw that the nontax problems associated with rehabilitation could not be discounted when considering the relative merits of new construction versus rehabilitation. ${ }^{87}$ The number of potential problems that exist in developing a rehabilitation project, in addition to those in qualifying for the credit, make the neutral tax choice argument a strawman. Although rehabilitation is taxfavored over new construction, other nontax aspects may indeed make the overall decision of whether to rehabilitate or build proceed on neutral ground. 88

Assuming, other things being equal, that it is better to rehabilitate than to build, it is difficult to say just how much more favorable the tax treatment of rehabilitation needs to be to encourage such behavior. Moreover, although Congress' intent, as expressed in the legislative history, ${ }^{89}$ was to revitalize and prevent the decay of older locations, it is not evident how the decision was made as to the amount of credit necessary to encourage investment.

85. Brownstein \& Lore, Tax Act Should Encourage Historic Preservation, Washington Legal Times, Sept. 28,1981 , at 27.

86. Gensheimer, supra note 58 , at 314 .

87. These nontax considerations include the availability of financing and expertise, the readiness of occupancy, the risk of unsound structural framework, and the costs of nonstandard supplies. Limberg \& Black, An Analysis of the Inventives Provided by the Rehabilitation Tax Credit, $1983 \mathrm{~J}$. TAX'N 386.

88. Supply also limits the potential favoritism for rehabilitation tax credits.

89. S. Rep. No. 144, 97th Cong., 1st Sess. 72, reprinted in 1981 U.S. Code Cong. \& Ad. News 177; see supra text accompanying note 2. 
Theoretically, the credit should be set at a level where it would give a return just above a new project. In the warehouse example given above, the investor looking at the two possible choices would be indifferent with a $9 \%$ credit (that is, his tax savings would be the same in both projects). ${ }^{90}$ While the potential problems mentioned above would necessitate having a larger credit to achieve true indifference, the necessary increase is unlikely to be large enough to make the credit $25 \% .{ }^{91}$ Therefore, strictly on efficiency grounds, it seems that the marginal cost of the credits exceeds the marginal benefit because a smaller, less costly credit could be used to achieve similar results. Without more data, it is not possible to say exactly where this efficient point is, but one can say that the current credit scheme seems to be much too generous to achieve the goal of encouraging investment at the lowest cost.

The ceiling on tax credits and the alternative minimum tax ${ }^{92}$ indirectly cap the amount of potential revenue leakage from the rehabilitation credits, however, by limiting the amount of credits that may be taken without suffering a tax penalty. While the tax system limits the credits each taxpayer may take, it does not place a limit on the aggregate use of these credits; the question of efficiency remains.

\section{B. Certified versus Noncertified Structures}

As discussed above, the favored status of CHS over non-CHS buildings afforded by higher tax credits and by the lower basis recapture may encourage investors to seek certification of the structures they wish to rehabilitate. While these provisions ${ }^{93}$ certainly encourage certification, ${ }^{94}$ they may actually have perverse consequences for investors. One set of consequences results from the " 'all or nothing' catch"95 in the Code. That is, to be eligible for a credit a CHS must be rehabilitated according to the Secretary of Interior's standards. The owner does not have the option of failing to comply with the standards and taking the lesser $15 \%$ or $20 \%$ credits, depending on the building's age. ${ }^{96}$ If the project is not approved, he will be denied any credit. Even though the Interior Department's ten standards are arguably very broad, ${ }^{97}$ it is

90. This means that the credit would only have to have been $9 \%$ for him to have been indifferent between the two projects, while in reality he was not indifferent because the credit was $25 \%$.

91. See supra notes $\mathbf{7 3 - 7 5}$ and accompanying text.

92. I.R.C. 8 83(a)(3)(B), 55(a) (Lawyers Co-op. 1984).

93. Id. \& $48(\mathrm{~g})(2)(\mathrm{c}),(3)$.

94. That is, if the cost of certification is less than the additional credit, certification will be encouraged.

95. Hild, supra note 68 , at 332 .

96. I.R.C. $\$ 48(\mathrm{~g})(2)$ (c) (Lawyers Co-op. 1984). A CHS can be individually registered or certified by the Secretary of the Interior as being in a historic district.

97. Hild, supra note 68, at $329-30$. These standards are: (1) the property should be used in a way that will require minimum alteration; (2) historic material or architectural features should not be removed; (3) deteriorated features should be repaired rather than replaced; (4) examples of skilled craftsmanship or stylistic features should be treated with sensitivity; (5) changes made over time should be respected; (6) alterations should not seek to recreate an earlier appearance; (7) contemporary designs should be compatible with existing designs; (8) additions should not alter the essential form and integrity of the building; (9) every reasonable effort should be made to protect 
nevertheless true that the investment decision based on favorable tax consequences can result in a severe penalty for the investor who miscalculates. From the standpoint of preservation quality, it is probably worthwhile to insure that CHS's are rehabilitated in a proper manner; however, it may not be equitable for investors ${ }^{98}$ to be penalized so severely by losing their credit.

Another group of problems for investors results from the distinction between residential and nonresidential properties. Residential CHS's are the only type of residential properties eligible for the tax credit. ${ }^{99}$ Thus, an investor interested in residential property will tend to look towards new property, for which he is eligible for ACRS, or towards certified historic property, for which he is eligible for the $25 \%$ tax credit. Using the tobacco warehouse as an example, it is clear that the investor will choose to buy and develop the warehouse condominiums only if he can be relatively certain that the building will be certified as a historic structure. ${ }^{100}$ Owners of older nonhistorically significant buildings, such as old hotels (which do not qualify as commercial/industrial buildings), will find that they may be squeezed out of the investment picture because of the limited applicability of ACRS and the nonavailability of the rehabilitation tax credits. ${ }^{101}$

\section{VII}

\section{MACRO EFFECTS}

\section{A. The Use of Tax Credits for Preservation}

For fiscal year 1984, the Office of Management and Budget has estimated that the tax expenditure budget for rehabilitation tax credits will be $\$ 805$ million. ${ }^{102}$ This compares to estimates of $\$ 1.1$ billion for residential energy credits, $\$ 28.3$ billion for the mortgage interest deduction, and $\$ 115.6$ billion for general commerce and housing credits. ${ }^{103}$ Thus, the rehabilitation tax credits would seem to meet with little objection on the basis of their cost relative to the federal budget. However, critics have objected to the credits on policy grounds: "[I]t must be plainly recognized that the use of the tax

and preserve archaeological resources; and (10) the surface cleaning should be undertaken by the gentlest means possible.

98. In reality, it is possible to reapply for certification after an initial disapproval. This will ameliorate the total loss an investor might face, although the delay in having to reapply will undoubtedly cause some economic hardship for the investor.

99. I.R.C. \& 48(a)(3)(D) (Lawyers Co-op. 1984); see supra text accompanying note 77.

100. This also includes being part of a historic district.

101. Although allowing all three classes of rehabilitation credits to include residential properties would encourage more investors to take the credits, it seems to have been Congress' intention to limit the size and scope of the tax expenditure to all older commercial and industrial buildings and to historically significant residential buildings.

102. The Office of Management and Budget, Tax Expenditure Budget (FY 1984), in Readings IN Federal Taxation 167-68 (M. McIntyre ed. 1983). Of this total, $\$ 345$ million is for historic structures, and $\$ 460$ million is for nonhistoric structures.

103. Id. General commerce and housing credits include government subsidized mortgage loans and other similar programs. 
system to resolve specific social and economic problems is almost always at cross-purposes with these objectives." 104 In other words, although the United States government subsidized nearly 5,000 rehabilitation projects through tax credits during Fiscal Years 1976-1982,105 what was the effect of those subsidies? Furthermore, did the credits overshadow other goals by serving as an attractive real estate shelter?

Although it is premature to give a definitive response to these questions because of the short time since ERTA was enacted, a few observations can be made. First and foremost, most of those who are considering the use of rehabilitation tax credits are high tax bracket investors for whom an investment tax credit is most advantageous in offsetting tax liability. ${ }^{106}$ There is nothing per se wrong with encouraging high tax bracket investors to favor rehabilitation of buildings over other forms of investment. What does give pause for concern is that, even though " $[t]$ he willingness of private interests to rehabilitate or maintain an older property ... will depend in large measure on economic considerations, including tax considerations," 107 the use of tax credits may effectively distort the access to rehabilitation projects, vesting the control of rehabilitation of older structures in the hands of very few investors. The "substantial rehabilitation" requirement of the ERTA credits $^{108}$ further reinforces the fact that small projects (i.e., those less than $\$ 5,000$ ), and thus small investors, may be excluded from the credit. In theory, this means that low and moderate income individuals are, for the most part, unable to participate in these tax-favored rehabilitation ventures.

Nevertheless, it may be easy to overstate the severity of this problem. The GAO Report's survey results from 1979 show that even with the smaller preERTA credits nearly half of the individual taxpayers taking the credit had incomes below $\$ 40,000$, and two-thirds of the partnerships and corporations using the credits had total assets of less than $\$ 100,000.109$ Even though higher bracket individual and corporate taxpayers had higher rehabilitation expenditures in actual dollar amounts, and thus higher tax credits, ${ }^{110}$ the GAO's conclusion that "the benefits associated with the historic preservation tax expenditure have accrued, for the most part, to individuals at higher income levels and to partnerships and corporations at higher asset levels,"111 seems overstated. A small investor in a low tax bracket will benefit from a tax credit as much as or more than a high bracket investor, even if the latter has a

104. Caplin, Federal Tax Policy as an Incentive for Enhancement of the Built Environment, in TAX Incentives for Historic Preservation 11 (G. Andrews ed. 1981).

105. 2 Pres. L. ReP. 1012.

106. U.S. General Accounting Office, supra note 65, at 17.

107. Caplin, supra note 104 , at 9.

108. See supra notes 35 and 36 and accompanying text.

109. U.S. General Accounting Office, supra note 65, at 16.

110. For example, individual taxpayers with adjusted gross incomes of $\$ 100,000$ or more participated in only 48 of the 258 projects surveyed (about $20 \%$ ) but spent $\$ 6.0$ million of the $\$ 20.2$ million spent on rehabilitation (about $30 \%$ ). Corporations and partnerships with $\$ 500,000$ or more in assets participated in 24 of the 150 projects surveyed (about $15 \%$ ) but spent nearly half of the total spent ( $\$ 49$ million out of $\$ 80$ million spent by nonindividuals).

111. U.S. General Accounting Office, supra note 65, at 17. 
larger amount of eligible expenditures to be credited, because the percentage of the credit does not vary with the level of income. For example, if the owner of a rehabilitated certified single family home was eligible for a $25 \%$ credit, had a tax liability of $\$ 5000$ before the credit, and had $\$ 10,000$ in rehabilitation expenses, he would receive a $\$ 2500$ tax credit, thereby sheltering $50 \%$ of his tax liability. If the hypothetical warehouse owner, who is in a much higher tax bracket, has a tax liability of $\$ 40,000$, and spends $\$ 60,000$ on rehabilitation, he thereby receives $\$ 15,000$ in credits and shelters only $38 \%$ of his total tax liability of $\$ 40,000$. Thus, to say that benefits accrue disproportionately to the wealthy is incorrect, if one considers the relative impact of the credits. ${ }^{112}$

Two larger questions of fairness and equity remain. First, should the tax system allow a relatively small sector of society to reap gains from these rehabilitation projects? Second, is there a better way to insure that important cultural resources like historic buildings are preserved? ${ }^{118}$

If the fundamental goal is to maximize the number of rehabilitation projects, then the credit is probably the most feasible way of accomplishing that goal. ${ }^{114}$ The tax credit will maximize the number of projects because the credit is limited only by the supply of properties available and not by factors such as grant budgets. As long as there are investors and properties, the process can continue.

However, if the concern for the greater good also factors in social "spillover" effects ${ }^{115}$ from rehabilitation, a direct spending program, or even refundable tax credits, might allow more investors access to this program. By giving grants for rehabilitation work, the government would remove a bias against those who possess rehabilitation expertise but lack experience in tax matters. Refundability would allow investment by those for whom the nonrefundable tax credit does not add enough of an incentive (i.e., those whose tax burden is not reduced significantly). In addition, a direct spending program could be regulated much more closely before projects begin, whereas a tax credit is approved only after the money has been spent and the project completed. Choosing between rehabilitation projects before they begin would allow other factors, such as location, type of building, and benefit to the community, to be considered. This would probably minimize concentration of rehabilitation resources in expensive warehouse condominiums or trendy boutiques, and might lead to the selection of a more beneficial mixture of projects.

Once rehabilitation incentives are no longer a tax expenditure item and are made a direct on-budget program, however, a myriad of other problems

112. It is acknowledged that wealthier taxpayers, by virtue of their economic position, may be in a better position to use the credits because they are aware of them.

113. See Whitebread, supra note 49 , at 454 .

114. This assumes that a tax credit will be a fairer way of allocating tax benefits than a tax deduction, which would allocate tax advantages relative to income level rather than evenly across income classes.

115. "Spillover" effects mean that residents of an area might feel alienated if they are excluded from the ability to participate in the project. 
appear. First, while a direct spending program can more precisely select "desirable" projects for rehabilitation, it would have much larger administrative costs. Although the cost and the size of the program budget can be limited prospectively-in contrast to a tax expenditure which is only limited retrospectively-labor-intensive grant approval procedures can delay projects and cause money otherwise spent on rehabilitation to be spent on administrative costs. Direct spending programs are also susceptible to politicization, resulting in projects chosen not on merit, but on the basis of legislative compromises. Finally, the same nontax considerations that influence the choice of whether to qualify for a tax credit are also present when considering whether to apply for a rehabilitation grant. In other words, it is likely that many of those people who could take advantage of tax credits (i.e., high bracket taxpayers and corporations) would also be in a position to utilize grants.

\section{VIII}

\section{Conclusion}

As former IRS Commissioner and preservationist Mortimer Caplin stated:

We all have a deep interest in preserving the structural legacy of America. It is far better to live and work where the building heritage of many years is still alive than in the dread monotony that characterizes so much of modern development. As we assist revisions of the U.S. tax laws and probe for additional possible solutions, we must recognize that tax incentives by themselves are not sufficient. They can only be part of an overall preservation strategy, and the development of a total strategy is needed to achieve our ultimate goal. ${ }^{116}$

Although Caplin's remarks were made before the passage of ERTA and TEFRA, they are equally apt today. Changes made in the tax code by ERTA, granting rehabilitation tax credits for certain classes of buildings, are important for the preservation of decaying urban infrastructure. Yet, for distributional and economic reasons, the tax credit system is not perfect, and thus should remain only one method out of many for assisting the preservation of older structures.

116. Caplin, supra note 104 , at 12-13. 


\section{APPENDIX \\ New Project (Table 1): Explanation}

Column 1 assumes a $10 \%$ down payment in the first year of the project, or $\$ 10,000$ on a $\$ 100,000$ unit.

Column 2 assumes a rent of $\$ 600$ per month, or $\$ 7200$ yearly for all five years.

Column 3 assumes a condominium fee of $\$ 200$ per month, or $\$ 2400$ yearly for all five years.

Column 4 is calculated by applying the $175 \%$ declining balance method to the $\$ 100,000$ basis. Thus, $12 \%$ is depreciated the first year, $10 \%$ the second year, $9 \%$ the third year, $8 \%$ the fourth year, and $7 \%$ the fifth and final year. Note that some of this accelerated depreciation is recaptured if the project is sold before the end of its useful life (fifteen years for purposes of this example). See Column 7.

Column 5 assumes property taxes of $\$ 2000$ per year.

Column 6 assumes interest payments of $12 \%$ on the $\$ 90,000$ financed on a thirty-year mortgage.

Column 7 is calculated by adding Column 2 (rent) to Columns 3 through 6 (condominium fee, depreciation, taxes, interest). The resulting figure is an amount allowed as a deduction to the taxpayer. Assuming that the taxpayer is in the $50 \%$ bracket, the deduction is multiplied by $50 \%$ to determine the actual tax savings (i.e., the amount that the taxpayer will actually save on his tax liability). The total tax savings includes recapture for depreciation, which is determined by subtracting the amount of depreciation under a straight line method from the accelerated depreciation actually taken. The resulting amount is then multiplied by the capital gains rate (here $20 \%$ because the taxpayer is in the top bracket).

Column 8 is calculated by adding Columns 1 through 3 and 5 through 7 (Column 4, depreciation, is not included because it is not an out-of-pocket cost). The total is the actual amount that the investor must pay or will receive during each year of the investment.

Column 9 assumes a $10 \%$ discount rate in each year but the first, where the investor buys the project midway through the year and thus only faces a $5 \%$ rate.

Columns 10 and 11 are the present discounted tax savings and cash flow calculations. They are identical to Columns 7 and 8 except that they are reduced by the amount of the discount rate. For example, the tax savings in year one is $\$ 9391.65$. Discounted by $5 \%$ it is $\$ 8944.43$ (\$9391.65 times $95 \%)$. 


\section{Historic Building (Table 2): Explanation}

Except as noted, the calculations for the historic building are identical to the new project.

Column 4 is calculated on a fifteen-year straight line method. The basis is only $\$ 92,500$ because it is reduced by $50 \%$ of the $\$ 15,000$ tax credit. Therefore, $\$ 7,500$ is subtracted from the $\$ 100,000$ basis, resulting in an adjusted basis of $\$ 92,500$. Also note there is no recapture because the straight line method is used.

Column 7 includes the $\$ 15,000$ tax credit given in year one. This is calculated by multiplying the $25 \%$ rate times the amount of rehabilitation expenditures (assumed to be $\$ 60,000$ or about $60 \%$ of the total cost of the project). The credit is added to the tax savings amount after calculating it for the investor's tax bracket (i.e., $\$ 6475.15$ without the credit and $\$ 21,475.15$ with it). 


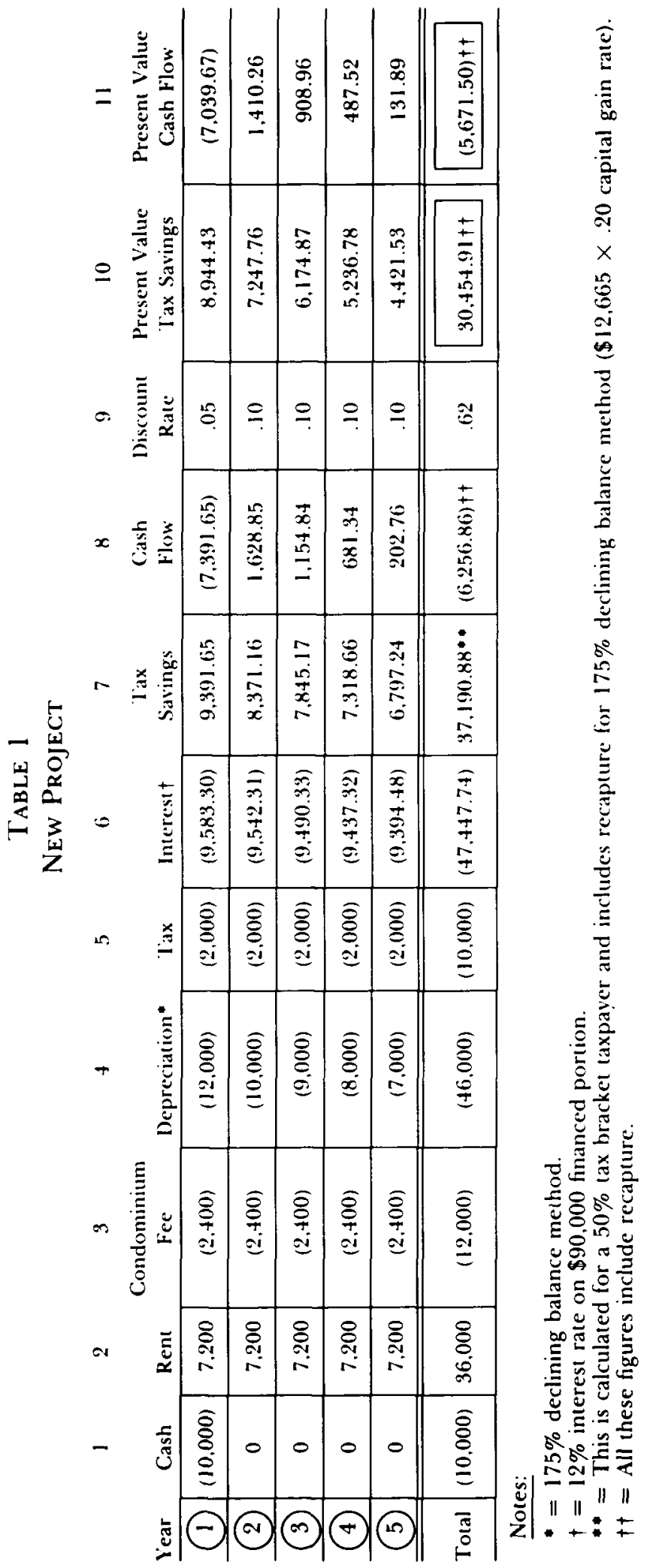




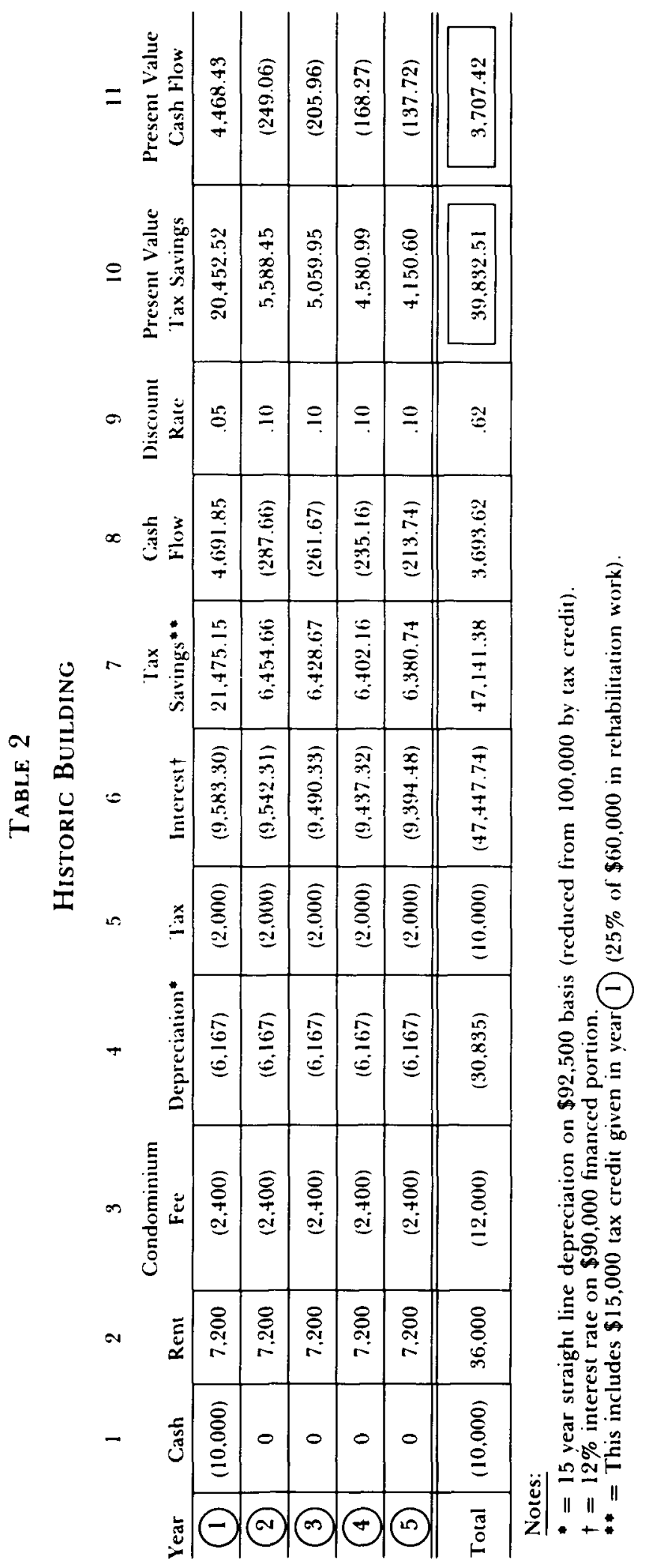

